УДК 502.17:620.91-049.5(477)(045)

JEL Q42, Q48

HETMAN O.L.

PhD in Economics

Senior Scientific Researcher, Department of economic and environmental problems of seaside regions

Institute of market problems and economic \&ecological researches of the National Academy of Sciences of

Ukraine,

Frantsuzkyi boulevard, 29, Odessa, Ukraine, 65044

E-mail: helenagetman24@gmail.com

ORCID: 0000-0002-7404-3738

\title{
PROPOSALS REGARDING FORMATION OF RISKS PREVENTING MECHANISMS TO ENVIRONMENTAL SOUND DEVELOPMENT IN THE FUEL AND ENERGY SECTOR
}

Topicality. Given the energy dependence of the country, existing energy, environmental and social threats to sound development due to increased tariffs for heat and electricity and rise in prices for products and services of all economic sectors, it is necessary to determine the strategic directions of risk management in the fuel and energy sector. The choice of a management option, based on the features of preventing and reduction of risk to a possibly low level in the fuel and energy sector, becomes particularly relevant.

Aim and tasks. The goal of the article is to substantiate the mechanisms for managing the environmentally sound development of the fuel and energy sector, to identify areas of the settlement and ways to minimize currently existing risks and measures aimed at preventing threats and risks in the fuel and energy sector of the economy.

Research results. The article substantiates and proposes mechanisms for managing the environmentally sound development of the fuel and energy sector. There are considered areas of the settlement and ways to minimize currently existing risks and measures aimed at preventing threats and risks in the fuel and energy sector of the economy.

There are represented systematic understanding of the logical connection between existing risks and their consequences depending on the source of threats and are defined monitoring phases of threats which should be the basis for making management decisions.

Analyzing the research of foreign and our scientists, we came to the conclusion that the use of alternative energy in the fuel and energy sector strengthens energetic and environmental safety and defied a number of necessary modern steps that will contribute to environmentally sound development of Ukraine.

Based on an analysis of the current state of usage of the energy resources and energy development in Ukraine, the need to increase the share of primary energy production from alternative energy sources, which can solve critical problems in the regions of Ukraine, was proved.

The study of international investment practice in the environmentally sound development of the country, the means and trends of stimulation allowed to propose organizational and managerial measures to ensure the efficiency of the mechanisms. It was proved that in order to obtain the most positive economic-environmental effect within the national energy it is necessary to give preference to projects with the highest investment efficiency to get positive economic, environmental, social and resource effects.

The necessity of applying an integrated approach to the formation of a system of mechanisms for providing an effective environmentally sound development of the fuel and energy sector, which synthesizes systemic, managerial, integrated, innovative approaches and allows to comprehensively explore the processes of management and use of alternative energy sources is substantiated. There is proposed the complex of mechanisms of national, regional, municipal ecologically oriented regulation of environmentally sound development of the fuel and energy sector.

Conclusions. It was established that the management of environmentally sound development of the fuel and energy sector is a complex of processes that ensure the transformation of existing problems into a new state through the application of certain controlled actions. The theoretical, methodological and conceptual basis for the establishment of a system for managing the environmentally-oriented development of the fuel and energy sector, the implementation of strategy and strategic management mechanisms that ensure long-term development on the basis of ecologization constitute the subject and prospects for further scientific research in this direction. measures.

Key words: environmental safety, energy security, management of environmentally sound development, preventive 
ГЕТЬМАН О. Л.

канд. екон. наук,

с.н.с. відділу економіко-екологічних проблем приморських регіонів

Інститут проблем ринку та економіко-екологічних досліджень НАНУ

Франиузький бульвар, 29, м. Одеса, Украӥна, 65044

E-mail: helenagetman24@gmail.com

ORCID: 0000-0002-7404-3738

\section{ПРОПОЗИЦЇ̈ ЩОДО ФОРМУВАННЯ МЕХАНІЗМІВ ПОПЕРЕДЖЕННЯ ВИНИКНЕННЯ РИЗИКІВ ЕКОЛОГОБЕЗПЕЧНОМУ РОЗВИТКУ В ПАЛИВНО-ЕНЕРГЕТИЧНОМУ СЕКТОРІ}

Актуальність. 3 урахуванням енергозалежності краӥни, існуючих енергетичних, екологічних та соиіальних загроз безпечному розвитку внаслідок підвищення тарифів на тепло і електроенергію та зростання цін на продукиію і послуги всіх секторів економіки виникає необхідність визначення стратегічних напрямків менеджменту ризику у паливно-енергетичному секторі. Вибір варіанту управління, в основу якого покладено особливості попередження та зниження ризику до можливо низького рівня у паливно-енергетичному секторі набуває особливої актуальності.

Мета та завдання. Метою статті є обгрунтування механізмів управління екологобезпечним розвитком паливно-енергетичного сектору, виявлення напрямків регулювання і способів мінімізаџї нині існуючих ризиків та превентивних умов щодо попередження виникнення загроз та ризиків у паливно-енергетичному секторі економіки.

Результати. У статті обтрунтовано та запропоновано механізми управління екологобезпечним розвитком паливно-енергетичного сектору. Розглянуто напрямки регулювання, способи мінімізаиії нині існуючих ризиків та превентивні умови щодо попередження виникнення загроз та ризиків в паливноенергетичному секторі економіки.

Представлено системне уявлення про закономірний зв'язок між існуючими ризиками та їх наслідками залежно від джерела загроз та визначено етапи моніторингу загроз, які мають бути підтрунтям для прийняття управлінських рішень.

Аналізуючи дослідження зарубіжних та вітчизняних вчених, дійшли висновку, що використання альтернативної енергетики в паливно-енергетичному сектору зміџнює енергетичну та екологічну безпеку та виділено ряд необхідних сучасних кроків, які будуть сприяти екологобезпечному розвитку України.

Спираючись на аналіз сучасного стану використання енергоресурсів та розвитку енергетики в Украӥні, доведено наявність потреби збільшення частики виробництва первинної енергії з альтернативних джерел енергії, які можуть вирімувати критичні проблеми у регіонах України.

Дослідження міжнародної практики інвестування в екологобезпечний розвиток держави, засобів та тенденцій стимулювання, дозволили запропонувати організаиійно-управлінські заходи забезпечення дісвості механізмів. Доведено, що для отримання максимально позитивного економіко-екологічного ефекту у рамках національної енергетики необхідно віддавати перевагу проектам з найвищою інвестиційною ефективністю для отримання позитивного економічного, екологічного, соиіального та ресурсного ефектів.

Обтрунтовано необхідність застосування комплексного підходу до формування системи механізмів забезпечення ефективного екологобезпечного розвитку паливно-енергетичного сектору, який синтезує системний, менеджментний, інтегрований, інноваційний підходи та дозволяе всебічно дослідити процеси управління та використання альтернативних джерел енергії. Запропоновано комплекс механізмів державного, регіонального, місиевого екологоорієнтованого регулювання екологобезпечного розвитку паливноенергетичного сектору.

Висновки. Встановлено, щзо управління екологобезпечним розвитком паливно-енергетичного сектору $є$ сукупністю прочесів, що забезпечують перетворення існуючих проблем в новий стан шляхом застосування певних керованих дій. Теоретико-методологічні та концептуальні засади створення системи управління екологоорієнтованим розвитком паливно-енергетичного сектору, запровадження стратегії та механізмів стратегічного управління, що забезпечують довгостроковий розвиток на засадах екологізаиії становлять предмет і перспективи для подальших наукових досліджень в даному напрямку.

Ключові слова: екологічна безпека, енергетична безпека, управління екологобезпечним розвитком, превентивні умови попередження виникнення ризиків.

Problem statement and its connection with important scientific and practical tasks. The importance of the environmentally sound development of the fuel and energy sector is primarily due to the huge costs of energy and natural resources in agriculture, industry, urban-industrial agglomerations, taking into account global climate change, rising energy prices, and environmental pollution. A compliance with the principle of safety is crucial in forming and institutionalizing organizational and economic management mechanisms at the global, national or regional levels. Analyzing the research of our and foreign scientists 
who considered the energy sector, we came to the conclusion that the use of unconventional energy sources in the energy sector strengthens both the energy and environmental safety of the country. To ensure the environmentally sound development of the fuel and energy sector, there are some objective and subjective reasons which are necessary for development and implementation alternative energy presented in Fig. 1.

\begin{tabular}{|l|l|l|l|} 
For ecologically safe development, it is necessary to reduce the negative impact of energy \\
producing objects
\end{tabular}

Fig. 1. Objective and subjective reasons which are necessary for development and implementation alternative energy

Source: author's development

Analyzing the vectors of the development of environmentally sound development of the fuel and energy sector in different countries, the following steps that will facilitate the implementation of environmentally sound development in Ukraine should be mentioned: increasing the share of use of alternative energy sources (wind, solar power plants, etc.); implementation of new types of energy sources; improvement of the regulating the energy sector legislation; the necessary level of public investment in promoting the development of ecology; providing the necessary national level of investment promotion in environmentally oriented development; formation of market conditions for the development of the energy industry; transition from energy saving to energy efficiency; promotion of environmental protection and energy efficiency in the manufacturing and consumer sectors (granting of benefits, loans with lower interest rates, incentive measures); use of technical means of achievement energy efficiency; a structural analysis of all energy-consuming sectors of the economy and the development of practical recommendations for energy conservation.

The development of alternative energy is a key element of sustainable environmentally sound development of the fuel and energy sector, provides a significant reduction in the negative impact on the environment, a more even distribution of energy resources, decentralization of energy production, and an increasing in the level of economic freedom of the country, which is one of the conditions for ensuring environmental and energy security of Ukraine.

Analysis of recent publications on the problem. For a long time a number of our scientists and researchers are engaged in researches of many problems in the development of the fuel and energy sector, including in the field of alternative energy and energy saving, energy and economic security such as: A. 
Galchinsky, J. Zhalilo, G. Zabarny, S. Kudrya, A. Shevtsov, A. Shidlovsky, V. Lipkan, N. Nyzhnik, G. Sitnik, M. Zemlyany, L. M. Gorbach and others. Among the foreign experts, in these studies are engaged: V. Weiss, A. Erdman, B. Zanner, W. Nordhaus, W. Rowe, W. Streicher, R. Young and others. On the basis of the literature analysis we reveled that scientists are considering issues of environmentally sound development of the fuel and energy sector from the point of view of the implementation of alternative energy, which strengthens energy security. Existing research is the basis for improving the mechanisms of management of environmentally sound development.

Allocation of previously unsolved parts of the general problem. Problems in forming preventive measures to ensure effective and environmentally sound development of the fuel and energy sector remain unresolved. The issues of management and use of alternative energy sources for elimination of socioecological and economic threats and risks are insufficiently substantiated.

Formulation of research objectives (problem statement). The goal of the article is to substantiate the mechanisms for managing the environmentally sound development of the fuel and energy sector, to identify areas of the settlement and ways to minimize currently existing risks and measures aimed at preventing threats and risks in the fuel and energy sector of the economy. A integrated approach to the formation of a system of mechanisms for providing the environmentally sound development of the fuel and energy sector in this study will be considered from the point of view of synthesis of systemic, managerial, integrated and innovative approaches that will comprehensively explore the processes of management and use of alternative energy sources and will facilitate the enhance the implementation of modern energy policy and elimination of existing socio-ecological and economic threats and risks.

Outline of the main results and their justification. Considering that the basis of energy today is energy resources, the main peculiarity of which is the limited inventory and exhaustiveness, as a result of which they can't be a guarantee of sustainable development of the world energy in the long-term perspective and taking into account the aspect, that their use is one of the main causes of the crisis in the environment, there is a need for the development of alternative energy as a key element of the impact on energy security and sustainable environmentally sound development of the fuel and energy sector.

The importance of the environmentally sound development of the fuel and energy sector is primarily due to the huge costs of energy and natural resources in agriculture, industry, urban-industrial agglomerations, taking into account global climate change, rising energy prices, and environmental pollution.Table 1 represents systematic understanding of the logical connection between problem situations and their consequences depending on the source of threats.

Table 1

The connection between problem situations and their consequences depending on the source of threats

\begin{tabular}{|c|c|c|}
\hline Source of threats & Factors of risk & Consequences \\
\hline \multirow{2}{*}{ 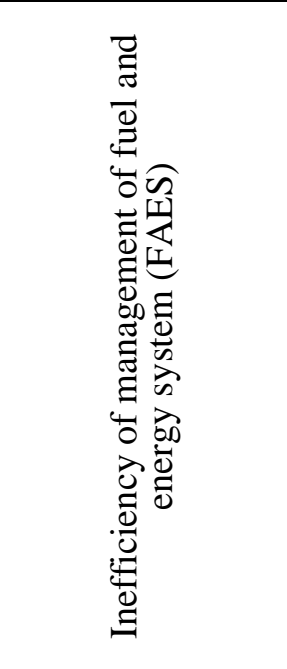 } & $\begin{array}{lr}\text { High } & \text { energy } \\
\text { dependence } & \text { of } \\
\text { Ukraine } & \end{array}$ & $\begin{array}{l}\text { - excessive dependence of Ukraine on external } \\
\text { monopoly suppliers of natural gas, oil and nuclear fuel (due } \\
\text { to increased demand for energy resources and limited } \\
\text { inventories of their traditional types in the world, as well as } \\
\text { high and volatile prices for them); } \\
\text { - excessive energy intensity of the branches of the } \\
\text { economy of the country, including the fuel and energy } \\
\text { complex, as well as the social sphere; } \\
\text { - structural and price imbalances of the energy balance } \\
\text { of the country }\end{array}$ \\
\hline & $\begin{array}{l}\text { The presence of non- } \\
\text { market and non- } \\
\text { transparent relations } \\
\text { in the FAES }\end{array}$ & $\begin{array}{l}\text { - administrative regulation of prices; - cross-subsidies } \\
\text { between individual categories of consumers and industries of } \\
\text { the FAES; } \\
-\quad \text { non-transparent privatization, monopolization of } \\
\text { regional energy markets; } \\
-\quad \text { absence of state strategic reserves of fuel and energy } \\
\text { resources; } \\
-\quad \text { destruction of scientific and technological potential } \\
\text { and low innovative activity of the FAES }\end{array}$ \\
\hline
\end{tabular}




\begin{tabular}{|c|c|c|}
\hline Source of threats & Factors of risk & Consequences \\
\hline \multirow{2}{*}{ 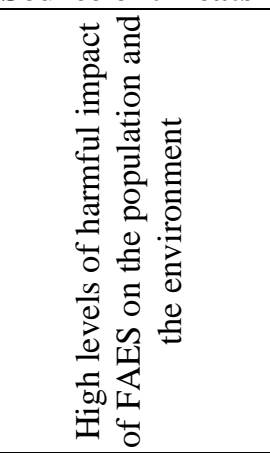 } & $\begin{array}{l}\text { The depletion and } \\
\text { reduction of natural } \\
\text { resources }\end{array}$ & $\begin{array}{l}\text { Decrease or termination of production activity of natural resources } \\
\text { enterprises, loss of workplaces, decrease of economic growth rates, } \\
\text { etc. }\end{array}$ \\
\hline & $\begin{array}{l}\text { The deterioration of the } \\
\text { quality of the } \\
\text { environment and, as a } \\
\text { result, human health } \\
\text { condition }\end{array}$ & $\begin{array}{l}\text { Increase in diseases of population due to environmental factors, } \\
\text { increases of costs for medical programs, changes in living } \\
\text { conditions, etc. }\end{array}$ \\
\hline \multirow{3}{*}{ 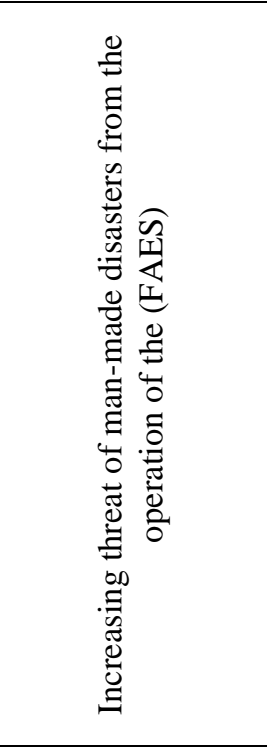 } & $\begin{array}{l}\text { Increase in technogenic } \\
\text { pressure due to the } \\
\text { development } \\
\text { additional } \\
\text { infrastructure }\end{array}$ & $\begin{array}{l}\text { The deterioration of the quality of the environment, decrease of the } \\
\text { assimilation capacity of the territory, deterioration of living } \\
\text { conditions of the population, economic losses from the reduction of } \\
\text { GDP, economic losses from environmental pollution and } \\
\text { deterioration of the health of the population, etc. }\end{array}$ \\
\hline & $\begin{array}{l}\text { Increase in technogenic } \\
\text { pressure due to the } \\
\text { growth of production } \\
\text { of resource-intensive } \\
\text { and low-tech }\end{array}$ & $\begin{array}{l}\text { The same, and also the reduction of budget incomes from the loss } \\
\text { of market value of the territory, restrictions on access to biological } \\
\text { resources, violations of inter-sectoral cooperation and territorial } \\
\text { connections, energy intensity of GDP, etc. }\end{array}$ \\
\hline & $\begin{array}{l}\text { The growth in the } \\
\text { number and magnitude } \\
\text { of man-made disasters }\end{array}$ & $\begin{array}{l}\text { The deterioration of the quality of the environment and living } \\
\text { conditions, economic losses from environmental pollution and the } \\
\text { deterioration of the health of the population, reduction of } \\
\text { production efficiency through increased costs for compensation } \\
\text { payments and costs for the elimination of consequences, } \\
\text { reconstruction, etc. }\end{array}$ \\
\hline
\end{tabular}

Source: $[1,2,3,4]$

A compliance with the principle of safety is crucial in forming and institutionalizing organizational and economic management mechanisms at the global, national or regional levels. Analyzing the research of our and foreign scientists who considered the issues of the energy sector, we came to the conclusion that the use of alternative energy sources in the energy sector strengthens the energy and environmental safety of country.

Ukraine has a significant technically feasible potential for the development of alternative energy, and in order to increase the share of primary energy production from its sources and strengthen its place in the energy balance, it is necessary to form economic, informational and regulatory provision for the mass implementation of such technologies. Such energy sources can solve critical problems in the regions of Ukraine and promote environmentally sound development of the country.

Key weaknesses in the use of alternative energy sources in the context of providing environmentally sound development of the fuel and energy sector and preventive measures for responding to risks are presented in Table 2.

The use of alternative energy sources provides a significant reduction in the negative impact on the environment, a more even distribution of energy resources, decentralization of energy production, and an increase in the level of economic freedom of the country, which is one of the conditions for ensuring the environmental and energy security of Ukraine.

The necessity of conducting systematic, comprehensive research of the mechanisms of national management and the application of new fundamental approaches to the formation of a management mechanism through energy saving and environmentally sound technologies in the context of ecologization of the fuel and energy sector of the country becomes of particular relevance in the modern country. 
Risks and preventive measures of response to the use of alternative energy in the context of environmentally sound development

\begin{tabular}{|c|c|c|c|}
\hline \\
\hline & Hydroelectric power plants & Solar power plants & Wind power plants \\
\hline $\begin{array}{l}\text { Risks } \\
\text { in } \\
\text { usage }\end{array}$ & $\begin{array}{l}\text { - the risk of land flooding; } \\
\text { - the risk due to the absence of a stationary } \\
\text { hydrometric post; } \\
\text { - the risk of changing ecological chains in the } \\
\text { certain rivers, water temperature; } \\
\text { - the risk of increasing greenhouse gas emissions } \\
\text { as a result of the intensification of the processes } \\
\text { of decomposition of organic compounds, etc; } \\
\text { - the absence of regulatory documents regarding } \\
\text { the design, construction and operation of small } \\
\text { hydroelectric power plants (the regulatory } \\
\text { framework for large hydroelectric power plants is } \\
\text { used) }\end{array}$ & $\begin{array}{l}\text { The risks due to } \\
\text { technological process } \\
\text { associated with the } \\
\text { production of new } \\
\text { materials for solar power } \\
\text { plants. }\end{array}$ & $\begin{array}{l}\text { - the use for construction of } \\
\text { wind power plants large in } \\
\text { area of land; } \\
\text { the threat of the death of } \\
\text { birds. }\end{array}$ \\
\hline $\begin{array}{l}\text { Preve } \\
\text { ntive } \\
\text { meas } \\
\text { ures } \\
\text { for } \\
\text { respo } \\
\text { nding } \\
\text { to } \\
\text { risks }\end{array}$ & $\begin{array}{l}\text { - development of a national program for the } \\
\text { development of small hydropower; } \\
\text { - reconstruction of the system of hydrometric } \\
\text { points of measuring water consumption on small } \\
\text { rivers; } \\
\text { - high-quality and multi-vector energy, } \\
\text { ecological and water management at all stages of } \\
\text { the life cycle of a small hydroelectric power } \\
\text { station HPS; } \\
\text { - to predict a ban on the construction of the SHPS } \\
\text { not only in the territories of the nature reserve } \\
\text { fund, but also upstream on the rivers that flow } \\
\text { through the nature protection and recreation areas; } \\
\text { - implementation of normative documentation on } \\
\text { the design, construction and operation of small } \\
\text { hydropower plants, which would formulate } \\
\text { environmental requirements }\end{array}$ & $\begin{array}{l}\text { - development of power } \\
\text { generating capacities. } \\
\text { Construction of } \\
\text { photovoltaic stations; } \\
\text { - development of } \\
\text { regulatory and legal } \\
\text { support for the } \\
\text { development of solar } \\
\text { energy; } \\
\text { - scientific and technical } \\
\text { support for the } \\
\text { development of solar } \\
\text { energy. }\end{array}$ & $\begin{array}{l}\text { - most of the used land can } \\
\text { be used for the production of } \\
\text { agricultural products (WPP } \\
\text { occupy } 1 \% \text { of the total } \\
\text { required territory, } 99 \% \text { can } \\
\text { be used); } \\
\text { - as the mortality of birds } \\
\text { from the traffic of cars is } \\
300 \text { times higher, and from } \\
\text { power lines is } 50 \text { times } \\
\text { higher than the WPP of } 1000 \\
\text { MW, it is necessary to use } \\
\text { more powerful wind turbines } \\
\text { and reduce the frequency of } \\
\text { their rotation; } \\
\text { - scientific and technical } \\
\text { support for the development } \\
\text { of wind energy. }\end{array}$ \\
\hline & Geothermal installation & All types of heat pumps & Bioenergy \\
\hline $\begin{array}{l}\text { Risks } \\
\text { in } \\
\text { usage }\end{array}$ & $\begin{array}{l}\text { - a sufficiently high temperature of geothermal } \\
\text { water is required; } \\
\text { - there is a need for a renewable cycle of the } \\
\text { flow (injection) of water (usually spent) into the } \\
\text { underground aquifer, which takes additional } \\
\text { energy consumption; } \\
\text { - there is possible local lowering of the earth's } \\
\text { surface, which leads to a destabilization of } \\
\text { terrestrial structures and changes in the landscape; } \\
\text { - with significant usage of geothermal waters, } \\
\text { there is possible an increase in seismic areas. }\end{array}$ & $\begin{array}{l}\text { - high cost of equipment } \\
\text { compared to traditional } \\
\text { boilers } \\
\text { - limiting climatic and } \\
\text { geographical order; } \\
\text { - the need for a thorough } \\
\text { technical-economic and } \\
\text { operational } \\
\text { substantiation for making } \\
\text { a decision on the } \\
\text { implementation of a heat } \\
\text { pump. }\end{array}$ & $\begin{array}{l}\text { The threat of realization of } \\
\text { implementation due to the } \\
\text { obstruction of the issuance } \\
\text { of technical terms for the } \\
\text { connection. }\end{array}$ \\
\hline $\begin{array}{l}\text { Preve } \\
\text { ntive } \\
\text { meas } \\
\text { ures } \\
\text { for } \\
\text { respo } \\
\text { nding } \\
\text { to } \\
\text { risks }\end{array}$ & $\begin{array}{l}\text { The implementation of new effective technologies } \\
\text { will significantly reduce the negative impact on } \\
\text { the environment, as well as get an additional } \\
\text { economic effect by extracting valuable } \\
\text { components. }\end{array}$ & $\begin{array}{l}\text { Creation of a mechanism } \\
\text { for management of } \\
\text { energy use by heat } \\
\text { pumps for autonomous } \\
\text { heat supply and } \\
\text { modernization } \\
\text { existing heat supply } \\
\text { facilities }\end{array}$ & $\begin{array}{l}\text { Change of the law "On heat } \\
\text { supply", which would give } \\
\text { priority access to the objects } \\
\text { of alternative heat } \\
\text { generation to the heating } \\
\text { networks. }\end{array}$ \\
\hline
\end{tabular}


The results of our research indicate that it is expedient to identify 8 main approaches that create the basis for the formation of risk preventing mechanisms for environmentally safe development in the fuel and energy sector: systemic, complex, legal, managerial, process, integrated, innovative, economic and environmental.

Among the most appropriate methods for conducting research on the energy saving potential of all aspects of life in Ukraine is a systematic analysis that can be applied to solving problems in any aspect of life of a society. Besides the systemic approach, there is also a managerial. The choice of a particular approach is reflected in the difference in the procedures of regulation of governing the management activities.

Thus, the "systemic" approach requires the systemic representation of the object of management and energy saving policy of the country that needs to be diversified and conform to modern organizational, technical and technological conditions should be based on it. And "managerial" - requires a systemic representation of management, which is reflected in various requirements for the special methods, means and tools of analysis and development of the mechanisms of management.

Therefore, it is expedient to use an integrated approach that takes into account technical, environmental, economic, organizational, social and psychological aspects when solving the risks prevention issues in the fuel and energy sector. That's why from our point of view a integrated approach is based on the synthesis of systemic and managerial approaches, which provides the formation of an effective risks preventing mechanism to the environmentally sound development of the fuel and energy sector of the country.

Let's consider a complex of mechanisms of ecologically oriented management at the national level. According to the results of theoretical study of represented scientific developments in this field, the conceptual provisions for a model construction for managing the environmentally sound development of the fuel and energy sector in the form of a flow chart for the selection of managerial decisions are presented in Fig. 2.

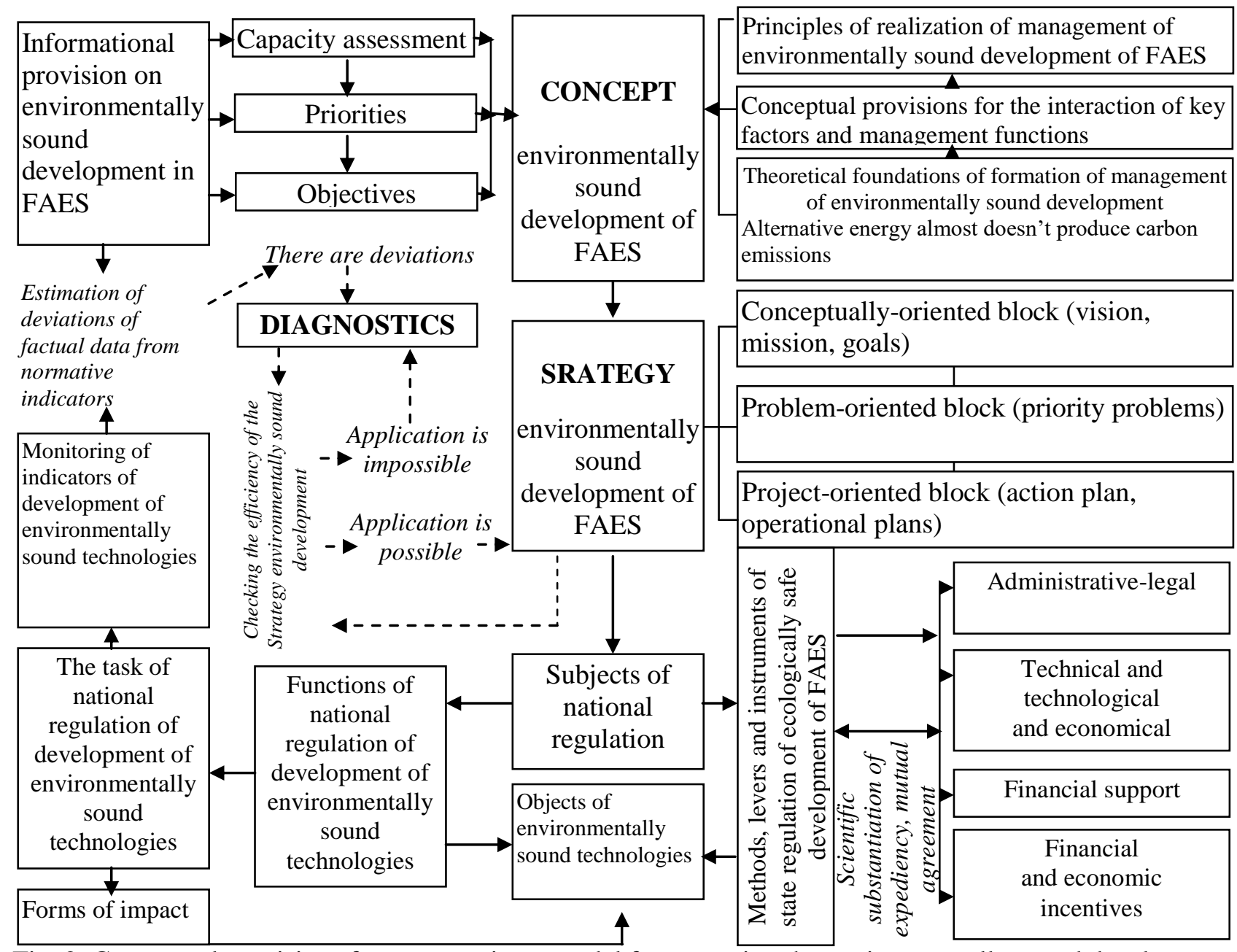

Fig. 2. Conceptual provisions for constructing a model for managing the environmentally sound development of the fuel and energy sector (SES) in an innovation-oriented economy Source: $[4,5]$

According to $[4,5]$, the stages of selection of managerial decisions are: 
1. Analysis of the information on the potential of environmentally sound development of the fuel and energy sector, considering modernization of operating power units, optimization of the production load on the TPP, implementation of alternative technologies.

2. Development of the concept of national regulation with an orientation towards the environmentally sound development of the fuel and energy sector and the strategy of alternative energy development, verification of its use on its basis.

3. Development of levers of organizational-economic, financial-economic and techno-technological influence, financial support, implementation of system-forming regulators to achieve a new state. The organizational-economic foundations of the mechanism of environmentally sound development of the fuel and energy sector are presented in Fig. 3.

\section{Organizational-economic foundations of mechanism of environmentally sound development of fuel
and energy sector}

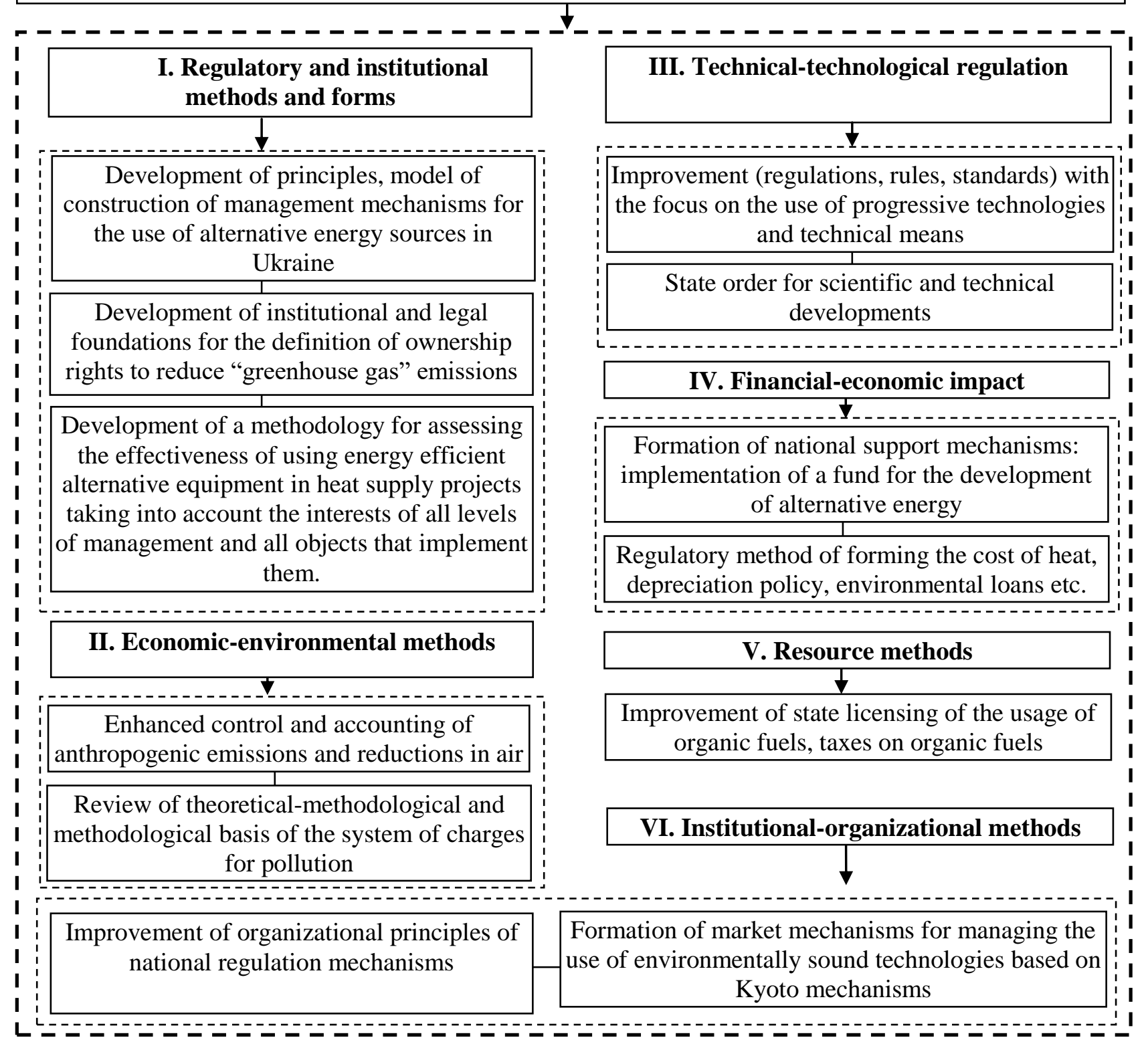

Fig. 3. Organizational-economic foundations of mechanism of environmentally sound development of

Source: author's development

fuel and energy sector

4. Monitoring of indicators for environmentally sound development of fuel and energy sector and estimation of deviations of actual data from normative indicators. 
As mechanisms of techno-technological regulation, the following are applied: 1) a system of standards, norms, regulations, oriented towards the use of progressive technical means and technologies of energy supply; 2) norms (limits) for the emission of pollutants into the air and discharges into water objects corresponding to advanced techno-technological means.

To economic regulatory mechanisms should be included: 1) price mechanisms and methods for calculating production costs and the cost of heat. Regarding the policy of pricing energy products, especially heat energy, it should be aim at inner reforming of all aspects of the industry and especially strengthening of all factors of the strategic development of alternative energy considering its high potential. Thus, we propose a transition to a normative method of forming the cost of heat with an orientation towards the use of progressive energy equipment, including an alternative to the reduction in the cost of organic fuels and emissions into the atmosphere, which will lead to a reduction in the cost of heat in central heating. Besides the item of material costs in forming the cost of a unit of thermal energy, another, equally important item of operating expenses, depreciation of fixed assets needs to be revised. According to the National Statistics Service of Ukraine, the level of general wear of fixed assets of the heat and power complex is more than $60 \%$, for individual heat supply facilities this indicator reaches $97,5 \%$. Such indicators are incompatible with the European standards, which indicates a long way to reduction the tariffs for heat. From the economic point of view, depreciation of fixed assets of the enterprise is one of the sources of self-financing of economic activity. However, the high level of the wear of fixed assets explains the low level of financing availability due to depreciation. According to the fact that in different regions of our country the price of heat is different, the reduction of the cost price of 1 Gcal depends on the approval of the investment component in the regions, such as: updating; recovery of networks; reconstruction; the implementation of alternative energy sources. 2) Depreciation of policy and depreciation norms for progressive environmentally sound technical-technological means.

The reduction of the share of material costs in the structure of the cost price is possible by replacing the share of traditional fuel and energy resources with alternative energy (low and medium potential energy, VER, solar energy, soil, water, etc.), which is currently for free. The article "depreciation of fixed assets" can be reduced through technical-technological changes, that is, the replacement of fixed capital with energy-saving environmentally sound technologies, which will increase the coefficient of suitability of fixed assets, which is about 3\% at some objects of generating sources. This causes high expenses for heat energy now at the stage of heat production, but there is still a heat network, the technological state of which is poor. The amount of depreciation deductions mostly depends on the method of depreciation of fixed assets adopted and approved by the order on the accounting policy of the enterprise, and the period of their useful use, defined according to with the Tax Code of Ukraine. According to the last, there are 5 methods of depreciation provided for, which are also defined by the Standard (accounting standard) №7 «Fixed assets». From our point view, it is appropriate to define not only the minimum period of use of fixed assets, but also the maximum, or the degree of maximum wear of equipment. Then enterprises will have to keep a clear record of the depreciation of their core funds, to make optimal investment decisions and to increase level of energy efficiency. It should be noted that to the projects of innovation and technological development, the method of accelerated depreciation corresponds most, which allows expanding opportunities for innovations. The advantage of this method is that during the first years of using the equipment, the necessary amount of money for its restoration is accumulated. This method makes it possible to reimburse up to $60-70 \%$ of the cost of equipment during the first half of the useful period of its usage.

The mechanisms of financial and economic incentives include: 1) the system of taxes on both the use of organic fuel and the pollution of the natural environment (taxes on $\mathrm{CO}_{2}$, coverage of losses for environmental pollution); 2) market mechanisms of the Kyoto Protocol; 3) specialized national financial funds; 4) benefit taxation.

As financial and economic incentive mechanisms in the practice of developed countries in order to stimulate alternative energy development and restrict the use of organic fuels, there are mainly used two types of tax mechanisms: 1) the tax on organic fuels (its size amounts to up to $20 \%$ of the already high cost of organic types of fuel - natural gas, oil, coal, etc.); 2) $\mathrm{CO}_{2}$ emission tax on the combustion of organic fuels. It should be noted that the systems of technical-technological and financial-economic regulation are very closely interrelated, because the $\mathrm{CO}_{2}$ taxation system is oriented on the norms of $\mathrm{CO}_{2}$ emissions, which are much lower when using progressive environmentally sound technologies.

It should be emphasized that the high prices and taxes on organic fuels encourage entrepreneurs and heat producers to implement investment projects in the field of energy saving and alternative energy supply, 
including at the level of development of technical-technological "know-how". At the same time, the policy of developed countries makes it easier for entrepreneurs and producers to realize these tasks, because: 1) major programs are being implemented at the national level for the development of new technical means and technologies in the field of increasing energy supply; 2) programs of environmental protection (including atmospheric protection means), in their serial production are implemented are implemented at the national level.

In order for financial and economic mechanisms to work in the country and to fulfill the international obligations of Ukraine, it is necessary today: to adopt the Law on Monitoring, Verification and Reporting (MRV), the Law on the scheme of greenhouse gas emission trading; to agree on the principles for distribution quotas for greenhouse gas emissions; to deal with the issue of size and distribution of carbon taxes.

The validity of managerial decisions at the regional, municipal level and business entities depends on compliance with the main principles of the national policy of ensuring the development of alternative energy. The proposed principles are based on the general principles of the adoption and realization of management mechanisms through the implementation of progressive environmentally sound technologies (Table 3).

Table 3

Conceptual principles of construction of management mechanisms of the environmentally sound development of the fuel and energy sector

\begin{tabular}{|c|c|}
\hline Principles & Characteristic \\
\hline $\begin{array}{l}\text { The principle of } \\
\text { purposefulness }\end{array}$ & $\begin{array}{l}\text { The main purpose of the functioning of the management mechanism is to } \\
\text { provide energy and environmental safety on the basis of optimization of } \\
\text { energy resources costs and minimization of the negative impact on the } \\
\text { environment in accordance with international requirements. }\end{array}$ \\
\hline $\begin{array}{l}\text { The principle of } \\
\text { interrelation and } \\
\text { interdependence, } \\
\text { stimulation and support }\end{array}$ & $\begin{array}{l}\text { The system of mechanisms should take into account the interests (economic, } \\
\text { social and environmental) of all participants in the process of development } \\
\text { of alternative energy. }\end{array}$ \\
\hline $\begin{array}{l}\text { The principle of } \\
\text { functionality }\end{array}$ & $\begin{array}{l}\text { The management mechanisms should be aimed at the realization of the } \\
\text { National Energy Strategy and combine management functions (planning, } \\
\text { organization, motivation, control, regulation). }\end{array}$ \\
\hline $\begin{array}{l}\text { The principle of } \\
\text { development }\end{array}$ & $\begin{array}{l}\text { The ability to improve management mechanisms based on the } \\
\text { harmonization of energy, economic, technical and environmental factors in } \\
\text { the management process. }\end{array}$ \\
\hline $\begin{array}{l}\text { The principle of } \\
\text { objectivity, specification } \\
\text { and accuracy }\end{array}$ & $\begin{array}{l}\text { The management mechanisms should be built on objective and reliable } \\
\text { information, which allows making informed decisions. In order to improve } \\
\text { the accuracy and reliability of analytical calculations, the process of } \\
\text { collecting, processing, analyzing and recording information should be } \\
\text { constantly improved. }\end{array}$ \\
\hline $\begin{array}{l}\text { The principle of consumer } \\
\text { orientation }\end{array}$ & $\begin{array}{l}\text { The management mechanisms should be aimed at guaranteed, } \\
\text { environmentally sound heat supply taking into account the consumer's } \\
\text { solvency. }\end{array}$ \\
\hline $\begin{array}{l}\text { The principle of economic } \\
\text { and environmental } \\
\text { efficiency }\end{array}$ & $\begin{array}{l}\text { Ensuring the adoption of the most effective heat supply option from the } \\
\text { point of view of the economic and environmental interests of the } \\
\text { participants in the process of implementation alternative technologies. }\end{array}$ \\
\hline $\begin{array}{l}\text { The principle of } \\
\text { continuity }\end{array}$ & $\begin{array}{l}\text { The management mechanism should include a monitoring, institutional- } \\
\text { legal, institutional-organizational and informational component that ensures } \\
\text { high responsiveness to changes and threats in the management system. }\end{array}$ \\
\hline $\begin{array}{l}\text { Principle of responsibility } \\
\text { and hierarchical co- } \\
\text { subordination }\end{array}$ & $\begin{array}{l}\text { Lies in is necessity to report to the supreme governing body and } \\
\text { responsibility for the coherence and validity of the decisions taken. }\end{array}$ \\
\hline $\begin{array}{l}\text { The principle of } \\
\text { transparency }\end{array}$ & $\begin{array}{l}\text { Lies in the possibility of obtaining relevant information and bringing the } \\
\text { decisions taken to the attention of all interested stakeholders (individuals } \\
\text { and legal entities) in the implementation of alternative energy projects. }\end{array}$ \\
\hline
\end{tabular}

Source: author's development 
These conceptual principles provide the basis for the mechanism of effective management in making managerial decisions at the subject-object level of various sectors of the national economy and preventing the emergence of risks to environmentally sound development in the fuel and energy sector.

Conclusions and perspectives of further research. The use of alternative energy in the fuel and energy sector strengthens energy and environmental security. An analysis of the current state of energy usage and energy development in Ukraine proves the need to increase the share of primary energy from alternative energy sources that can solve critical problems in the regions of Ukraine. The application of an integrated approach to the formation of a system of mechanisms for ensuring an effective environmentally sound development of the fuel and energy sector allows us to comprehensively explore the management processes and usage of alternative energy sources. The proposed complex of mechanisms of state, regional, municipal, environmentally-oriented management of the development of the fuel and energy sector will ensure the transformation of existing problems into a new state through the application of certain controlled actions.

The prospects for further scientific research in this area will be theoretical and methodological and conceptual foundations for the establishment of a system for managing the environmentally-oriented development of the fuel and energy sector, the implementation of strategies and strategic management mechanisms that ensure long-term development on the basis of ecologization.

\section{ЛІТЕРАТУРА}

1. Васюта О. А. Екологічна політика: національні та глобальні реалії: у 4 т. / О. А. Васюта, С.І. Васюта, Г.Г. Філіпчук. - Чернівці: Зелена Буковина, 2004. - Т.2. - 520 с.

2. Поворозник Р. В. Регуляторні механізми реалізації екологічної політики на регіональному рівні у контексті забезпечення їх стійкого розвитку [Електронний ресурс] / Р. В. Поворозник // Державне управління: удосконалення та розвиток. - 2011. №11. - Режим доступу: http://www.dy.nauka.com.ua/.

3. Гімер Р. Р. Загрози енергетичній безпеці України та заходи протидії їм [Електронний ресурс] / P. Р. Гімер //- Режим доступу: http://biomass.kiev.ua/images/news/pdf/letter_gimer.pdf

4. Державне регулювання розвитку сфери відновлювальної енергетики в Україні: теорія, практика, механізми : монографія / О. Ю. Стоян. - Миколаїв: Ємельянова Т. В., 2014. - 387 с.

5. Механізми підвищення енергетичної безпеки України в посткризовий період на основі використання потенціалу альтернативних джерел енергії /Гетьман О. Л.// в кн. Потенціал сталого розвитку стратегічних ринків України /Лайко О. І., Нікішина О. В., Гетьман О. Л. та інші; НАН України, ІПРЕЕД НАН України, 2014, с. 464.

6. Жаліло Я. А. Економічна стратегія держави: теорія, методологія, практика : монографія / Я. А. Жаліло. - К.: НІСД, 2003. - 368 с.

7. Енергоефективність та відновлювальні джерела енергії / С. М. Бевз та ін. НАН України. - К.: Українські енциклопедичні знання, 2007. - 560 с.

8. Науково-пізнавальне видання «Енергетика: історія, сучасність, майбутнє» [Електронний pecypc]. - Режим доступу: http:// energetika.in.ua/ua/books/book-5/part-3/section-5.

9. Национальный проект «Энергия природы»: особенности и перспективы реализации / В. А. Точеный, С. А. Кудря, Б. Г. Тучинский, А. В. Пепелов // Альтернативная энергетика и экология : международный научный журнал. - ISJAEE. -2012. №7 (111). - с. 137-142.

10. Теплонасосна енергетика в екологізації паливно-енергетичного комплексу України: перспективи розвитку та механізми управління: Монографія / Громова О. М., Гетьман О. Л., Маркова Т. Д. - Одеса: ІПРЕЕД НАН України, 2013, с.29.

11. Экономика Украины, Сердюк А. С., №4 (669), 2018. - с. 30-45.

12. Суходоля О. М. Системний аналіз механізмів державного управління у сфері енергоефективності / О. М. Суходоля // Державне управління: теорія та практика. - № 2. - 2005. Режим доступу: http://www.irbis-nbuv.gov.ua

\section{REFERENCES}

1. Vasyuta O. A. \&H.H. Filipchuk (2004). Ekolohichna polityka: natsionalni ta hlobalni realiyi: u 4 t. [Environmental policy: national and global realities: 4 toms.]/ - Chernivtsi: Zelena Bukovyna, - T.2. - 520 s. [in Ukrainian]

2. Povoroznyk R. V. (2011) Rehulyatorni mekhanizmy realizatsiyi ekolohichnoyi polityky na rehionalnomu rivni u konteksti zabezpechennya yikh stiykoho rozvytku [Regulatory mechanisms for the 
implementation of environmental policy at the regional level in the context of ensuring their sustainable development] / Derzhavne upravlinnya: udoskonalennya ta rozvytok. - №11. - Retrieved from: http://www.dy.nauka.com.ua/. [in Ukrainian]

3. Himer R. R. Zahrozy enerhetychniy bezpetsi Ukrayiny ta zakhody protydiyi yim [Threats to Ukraine's energy security and measures to counteract them ] - Retrieved from: http://biomass.kiev.ua/images/news/pdf/letter_gimer.pdf [in Ukrainian]

4. O. Y. Stoyan (2014). Derzhavne rehulyuvannya rozvytku sfery vidnovlyuvalnoyi enerhetyky v Ukrayini: teoriya, praktyka, mekhanizmy : monohrafiya [State regulation of the development of the renewable energy sector in Ukraine: theory, practice, mechanisms: monograph] - Mykolayiv: Yemelyanova T. V., - 387 s. [in Ukrainian]

5. Layko O. I.,\& Nikishyna O. V., \&Hetman O. L. (2014) Mekhanizmy pidvyshchennya enerhetychnoyi bezpeky Ukrayiny $v$ postkryzovyy period na osnovi vykorystannya potentsialu alternatyvnykh dzherel enerhiyi. Potentsial staloho rozvytku stratehichnykh rynkiv Ukrayiny - [Mechanisms for Enhancing Ukraine's Energy Security in the Post-Crisis Period on the Basis of Using the Potential of Alternative Energy Sources] / NAN Ukrayiny, IPREED NAN Ukrayiny, 2014, s. 464. [in Ukrainian]

6. Zhalilo Y. A. (2003). Ekonomichna stratehiya derzhavy: teoriya, metodolohiya, praktyka : monohrafiya [Economic strategy of the state: theory, methodology, practice: monograph]- K.: NISD, - $368 \mathrm{~s}$. [in Ukrainian]

7. S. M. Bevz ta in. NAN Ukrayiny (2007). Enerhoefektyvnist ta vidnovlyuvalni dzherela enerhiyi [Energy Efficiency and Renewable Energy]- K.: Ukrayinski entsyklopedychni znannya, - 560 s. [in Ukrainian]

8. Naukovo-piznavalne vydannya «Enerhetyka: istoriya, suchasnist, maybutnye» - Retrieved from: http:// energetika.in.ua/ua/books/book-5/part-3/section-5. [in Ukrainian]

9. V. A. Tochenyy, \& S. A. Kudrya, B. H.(2012) Natsyonalnyy proekt «Énerhyya pryrody»: osobennosty y perspektyvy realyzatsyy. Alternatyvnaya énerhetyka y ékolohyya : mezhdunarodnyy nauchnyy zhurnal. [ National project "Energy of nature": features and prospects of realization. ]ISJAEE. №7 (111). - s. 137-142. [in Russian]

10. Hromova O. M., \& Hetman O. L., Markova T. D. (2013). Teplonasosna enerhetyka v ekolohizatsiyi palyvno-enerhetychnoho kompleksu Ukrayiny: perspektyvy rozvytku ta mekhanizmy upravlinnya: Monohrafiya [Heat Pump Power Engineering in Environmentalizing the Fuel and Energy Complex in Ukraine: Perspectives of Development and Management Mechanisms: Monograph] - Odesa: IPREED NAN Ukrayiny, s.29. [in Ukrainian] Russian]

11. Serdyuk A. S., (2018) Ékonomyka Ukrayny - [Economy of Ukraine] №4 (669), - s. 30-45. [in

12. Sukhodolya O. M. (2005) Systemnyy analiz mekhanizmiv derzhavnoho upravlinnya u sferi enerhoefektyvnosti / Derzhavne upravlinnya: teoriya ta praktyka - [System analysis of public administration mechanisms in the field of energy efficiency] - № 2. - 2005. - Retrieved from: http://www.irbis-nbuv.gov.ua [in Ukrainian] 